\title{
Drug wars in the United States
}

\author{
R J Epstein
}

The recent declaration by President George Bush of a war on drugs raised few eyebrows here in the United States, coming as it did on the heels of identical but ultimately impotent Reaganist rhetoric. Paradoxically, the most visible effect of the announcement has been to make many people confront the failure of traditional prohibition style policies in controlling illicit drug use among American ghetto dwellers and middle class youth alike. ${ }^{1}$ The result has been the renewal of a debate which has long been an anathema to the people of this country: the question of legalising drugs. ${ }^{23}$

How much of the debate is based on rational argument and how much on good old fashioned gut feeling ("I don't know much but I know what I like") is fairly easy to assess. There has been little rational argument. A feature article on legalising drugs in Time magazine in 1988 began with a description of cocaine and heroin being sold in corner stores alongside vitamin tablets and herbal remedies, ${ }^{3}$ thus fostering the popular but inaccurate impression that legalising drugs is synonymous with their promotion. ${ }^{+}$Similarly, the Bush administration's resolve to fight drugs by imposing stiffer penalties on drug barons strikes a responsive chord in the American psyche" ("C'mon, boys, let's git them there rustlers and fill 'em full of lead") despite the demonstrable failure of this approach. ${ }^{26}$

The unpalatable realities of urban drug abuse in the United States are considerably more mundane than the sensationalist images suggest. Illicit drugs are popular because they make people feel good-or better-at least, than they customarily do. The American drug culture typifies this supply and demand mentality": "designer" drugs are increasingly popular, "recreational" drug use is an established national pastime, and phrases like "a quick fix" have infiltrated everday vocabulary. The drug market, however, differs from other consumer markets in two key respects. Firstly, the addictive nature of drugs weakens the price sensitivity of consumer demand, and, secondly, by declaring drugs illegal Western politicians have abandoned the opportunity to control drug supply. The combination of these two factors has provided a bonanza for exploitation by criminals and a continuing political nightmare for the status quo.

\section{Slavish devotion}

Politicians exist to serve the wishes of the people who elect them, of course, but to do so must first get elected. The upshot of this truism within the United States (exemplified in the 1988 presidential campaign) has been an ever more slavish devotion to the Messianic utterances of pollsters, those erstwhile barometers of public sentiment who now masquerade as political gurus, delivering statistically reinforced pronouncements on the electoral advantages and liabilities of any given political stance long before public declaration of policy is required. This has resulted in merging of Democrat and Republican party lines such that middle of the road conservatism is now perceived as mandatory for political survival while radical initiatives are mutually eschewed. ' Slogans such as "No new taxes" yield infinitely greater electoral benefits in the current

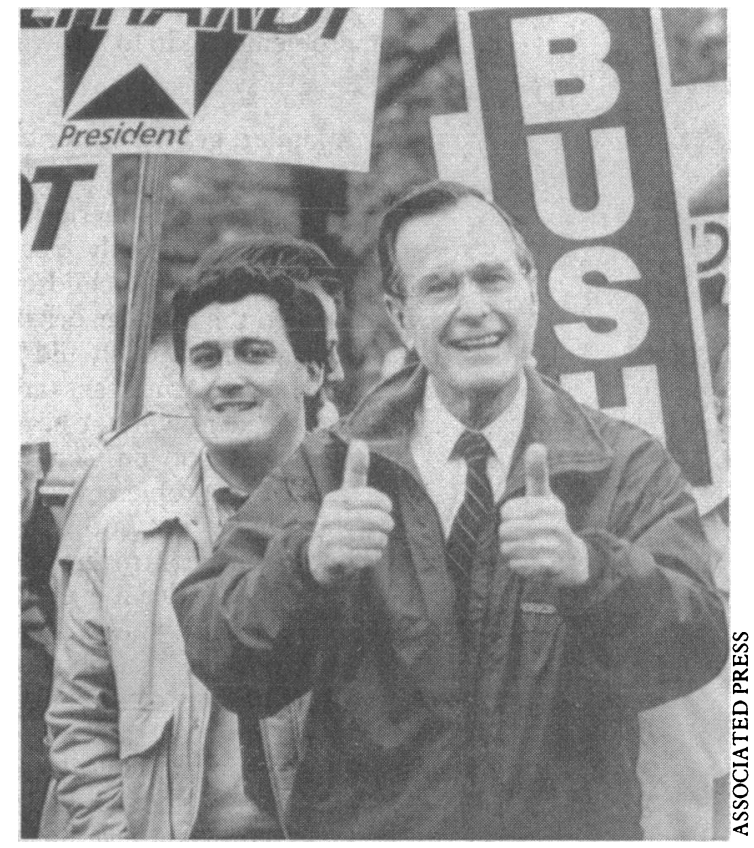

President George Bush, now campaigning against drug abuse

yuppy climate than do well intentioned but potentially disruptive strategies for dealing with complex issues such as the drug problem.

This brings us to the worrying issue of whether we are now seeing in the United States the fraying of a democracy which has hitherto defended the principle of individual freedom to the point of caricature. What the question boils down to is: can the long term interests of such a nation be entrusted to the short term vagaries of public opinion, given that it may be based on factors other than enlightened self interest? The normally humorous columnist in the New York Times Russell Baker recently suggested that public hypocrisy over the debate about legalising drugs reflects a national penchant for "aesthetic" opinion making" ("if it sounds yucky, forget it"), and it is difficult to avoid the conclusion that similar obsessions with aesthetics play a part in other divisive controversies, such as those concerning abortion, fetal research, genetic engineering, and animal rights. The problem with such issues from a political perspective is that the non-cerebral aesthetic response of several million voters is unlikely to be transformed by a prospective political candidate's 30 second spiel on the evening news. So it is, then, that politicians in the United States have become followers rather than creators of public opinion, puppets rather than prophets. ${ }^{7}$ We have entered an era in which the American public, guided by the editorial policies of multimedia business tycoons rather than by the constructive visions of statesmen, bear full responsibility for change.

It is therefore all the more remarkable to see change gradually seeping into the American drug debate. Individual journalists have chosen to speak out about alternatives to prohibiting drugs ${ }^{2+8}$ and the deficiencies of the current antidrug strategy. ${ }^{156} \mathrm{~A}$ recent article in Science declared that "the greatest beneficiaries of 
the drug laws are drug traffickers," while in the same week its transatlantic cousin, Nature, carried an editorial comment that the British free heroin drug rehabilitation programme "was too hastily abandoned twenty years ago." ${ }^{10}$ Could these words be giving voice to a new found courage in the face of the postVietnam drug epidemic, courage to admit when social policies have failed, to deal with the inevitable wrath of criminal interests, and to accept the risks implicit in any attempt at constructive reform? Slowly but surely, rightly or wrongly, an enlarging minority of Americans are coming to perceive throwing laws at the drug problem as akin to throwing antibiotics into a sewer.

\section{A kinder, gentler America}

George Bush vigorously promoted the slogan of "a kinder, gentler America" during his presidential campaign and was duly elected. In a recently televised address to schoolchildren, the avuncular Bush reiterated the message originally promulgated by Nancy Reagan, that kids should "Just say no" to drugs; in the same vein Americans are constantly reassured that their leaders will not be "soft on drugs," just as they were not "soft on Commies" in the McCarthy era." The main problem with this tired old war on drugs rhetoric lies not in the aesthetic appeal of the policies but in the incontrovertible proof that they have already failed. ${ }^{912} 13$ Indeed, even the White House administration is publicly pessimistic about the likely efficacy of such policies, ${ }^{1+}$ suggesting the adoption in private by United States officialdom of a fatalistic neoDarwinist perspective. With an estimated 40 million Americans regularly using illict drugs, ${ }^{12}$ drug offenders constituting over a third of inmates in already overcrowded federal prisons, ${ }^{9}$ over half of intravenous drugs users in
New York being positive for HIV antibody, ${ }^{15}$ the average age of first time drug users being 13 years, ${ }^{+}$and with the subversion and perversion of entire social systems by drug cartels now an established precedent, ${ }^{1617}$ can ordinary Americans afford to sit back and wait for the second coming of a leader like Bobby Kennedy to cut through the fog of expediency? Or will illumination only come through a painful realignment of mass sentiment as occurred with the Vietnam war? In the interests of "a kinder, gentler America," we can only hope that the speedier option will make itself known soon.

1 Berke RL. More of the same: Bush rejects basic shift for war on drugs. New York Times 1989 September 6:1

2 Becker GS. Should drug use be legalized? Business Week 1987 Aug 17:22-3.

3 Church GJ. Should drugs be made legal? Thinking the unthinkable. Time 1988 May 30:12-9.

4 Hamill P. Facing up to drugs: is legislation the solution? New York 1988 Aug 18:20-7

5 Wicker T. The wartime spirit: it could be dangerous in the drug war. New York Times Oct 3 1989:23.

6 Kifner J. Bush's drug war: scorn on besieged streets. New York Times 1989 Sept $8: 1$

7 Gaines R. The Dems doze. Boston Phoenix 1989 Sep 15:10.

8 Baker R. A question of good taste. New York Times 1989 Sept 6:25.

9 Nadelmann EA. Drug prohibition in the United States: costs, consequences and alternatives. Science 1989;245:939-47.

10 Anonymous. Bush declares war on drugs [Editorial]. Nature 1989;341:1-2.

11 Diamant A. The big lie. Boston Magazine 1988 Aug:138ff.

11 Diamant A. The big lie. Boston Magazine 1988 Aug:138ff. May:26-8.

13 Ryan R. A drug-prohibition plan that's doomed to fail. Boston Globe 1989 Oct $3: 19$

14 Berke RL. President's "victory over drugs" is decades away, officials say. New York Times 1989 Sept 24:1.

15 Des Jarlais DC, Friedman R, Novick DM, et al. HIV-1 infection among intravenous drug users in Manhattan, New York City, from 1977 through 1987. FAMA 1989;261:1008-12.

16 Anonymous. The quack epidemic [Editorial]. New Republic 1988 Nov 13: $7-10$

17 Treaster JB. US sending wrong equipment to fight drugs, Columbians say. New York Times 1989 Sept 12:1.

(Accepted 25 October 1989)

\section{ANY QUESTIONS}

What treatment is advised for excessive sweating, particularly of the axillae, hands, and feet?

Excessive sweating can be generalised-when a systemic cause such as hyperthyroidism, diabetes mellitus, occult infection, reticulosis, etc, should first be excluded-or focal, which usually has no clear organic cause. Focal hyperhidrosis starts after puberty and usually resolves spontaneously during the 20 s and 30 s. When there is no underlying cause treatment is symptomatic and may be surgical, electrical, or oral or topical drugs.

Axillary hyperhidrosis can usually be controlled - but not cured - by potent topical antiperspirants. A convenient treatment is the application at night, when the axilla is dry, for a week or so of aluminium chloride hexahydrate or aluminium chlorohydrate using a roll on stick. Treatment once a week may then suffice to maintain suppression ${ }^{1}$ but is not usually effective for hyperhidrosis of the palms and soles.

Iontophoresis is an effective remedy for many patients with hyperhidrosis of the palms and soles and may be used for axillae when topical antiperspirants fail. ${ }^{2}$ In this process a small current (up to 20 milliamps) at low voltage (up to 50 volts) is passed through the affected areas for five to 10 minutes twice weekly with tap water as the electrophoretic solution, and this may suppress sweating for many weeks. Maintenance treatment once a month may be required. It may be necessary to add to the water an anticholinergic drug such as glycopyrronium bromide or poldine methylsulphate. ${ }^{3}$ Equipment for iontophoresis is usually available in NHS physiotherapy departments, but there are commercial devices available for purchase by the public.

Oral anticholinergic drugs need to be given in such high doses to suppress hyperhidrosis that unwanted side effects-dry mouth, blurring of vision, glaucoma, and even convulsions - are more troublesome than the original complaint. Propantheline bromide, however, may be tolerated by many subjects in doses up to $150 \mathrm{mg}$ daily and suppress unwanted sweating with minimal side effects.

A last resort is surgery, either destruction of the relevant autonomic ganglia, when palms are affected, or extirpation of the sweating skin of the axillae. The former procedure can lead to permanent Horner's syndrome, hands that are too dry, or compensatory hyperhidrosis elsewhere, while the second procedure can be mutilating. Since hyperhidrosis is a self limiting disorder, admittedly lasting for a decade or so, surgery is rightly not a popular remedy. - ALAN B SHRANK, consultant dermatologist, Shrewsbury

1 Shelley WB, Hurley HJ. Studies on topical antiperspirant control of axillary hyperhidrosis. Acta Derm Venereol (Stockh) 1975;55:241-60.

2 Bouman HD, Grunewald Lentzer EM. Treatment of hyperhidrosis of hands and feet with constant current. Am f Phys Med 1952;31:158-69.

3 Grice K, Sattar H, Baker H. Treatment of idiopathic hyperhidrosis with iontophoresis of tap water and poldine methylsulphate. Br $\mathcal{F}$ Dermatol 1972;86:72-80.

\section{Is a gluten free diet of value in treating the irritable bowel syndrome?}

A gluten free diet is not, of itself, generally of value in patients with the irritable bowel syndrome. But some patients with coeliac disease have abdominal discomfort and variability of bowel habit, most often diarrhoea but sometimes constipation. So in patients with symptoms suggestive of the irritable bowel syndrome who do not respond to conventional measures small intestinal biopsies should be done to search for possible coeliac disease. If this is present a gluten free diet will be curative. There have been reports of food intolerance as a cause of the irritable bowel syndrome. ${ }^{12}$ These diagnoses have been made when symptoms improved after specific foodstuffs were omitted, with relapse when they were reintroduced. Dairy products have been particularly implicated, but wheat has also been a culprit in many instances. If the possibility of food intolerance is to be considered in patients with irritable bowel symptoms it should be done on the basis of careful dietary testing, for patients often believe that they are intolerant of a wide variety of foods and may limit their intake unjustifiably. - J R BENNETT, consultant physician, Hull

1 Jones VA, Shorthouse M, McLoughlan P, Workman E, Hunter JO. Food intolerance: a major factor in the pathogenesis of irritable bowel syndrome. Lancet 1982;ii:1115-7.

Nanda R, James R, Smith H, Dudley CRK, Jewell DT. Food intolerance and the irritable bowel syndrome. Gut 1989;30:1099-104. 